\title{
Kızılırmak Havzası'nda Sıcaklık Değerlerinin Trend Analizi
}

\author{
Özlem TERZi' ${ }^{* 1}$, Ahmet İLKER ${ }^{2}$ (1) \\ ${ }^{1}$ Isparta Uygulamalı Bilimler Üniversitesi, Teknoloji Fakültesi, İnşaat Mühendisliği Bölümü, 32200, Isparta, \\ Türkiye \\ ${ }^{2}$ Çankırı Karatekin Üniversitesi, Meslek Yüksekokulu, İnşaat Bölümü, 18200, Çankırı, Türkiye
}

(Alınış / Received: 07.02.2020, Kabul / Accepted: 25.08.2020, Online Yayınlanma / Published Online: 20.12.2020)

\section{Anahtar Kelimeler}

Kızılırmak Havzası,

Sicaklık,

Trend analizi,

Mann-Kendall testi,

Sen'in trend testi
Özet: Sıcaklık, yağış gibi meteorolojik parametrelerin trendini bilmek bu verilerin gelecekte nasıl bir davranış göstereceğini tahmin etmek açısından önemlidir. Bu çalışmada Türkiye'nin ikinci en büyük havzası olan Kızılırmak havzasındaki sekiz il merkezindeki meteoroloji istasyonlarının aylık minimum, maksimum ve ortalama sıcaklık verilerine trend analizi uygulanmıștır. Trend analizi, Devlet Meteoroloji İşleri Genel Müdürlügü̈nden temin edilen 1980-2017 yılları arasındaki 38 yıllık döneme ait veriler kullanılarak Mann-Kendall testi ile gerçekleştirilmiștir. Sen'in trend testi ise değişim miktarını belirlemek için kullanılmıştır. Yapılan trend analizleri sonucunda birçok noktada istatistiksel olarak anlamlı artış trendi olduğu görülmüştür. Ayrıca, havza sınırları içeresinde bulunan sekiz istasyon genelinde minimum, maksimum ve ortalama sıcaklıklarda artış trendi olduğu belirlenmiştir.

\section{Trend Analysis of Temperature Values in Kızllırmak Basin}

\section{Keywords}

Kızılırmak Basin, Temperature, Trend analysis, Mann-Kendall test, Sen's trend test

\begin{abstract}
Knowing the trends of meteorological parameters such as precipitation, temperature is significant in terms of predicting how these parameters will move in the future. In this study, the trend analysis was applied to monthly minimum, maximum and mean temperature data of meteorological stations located in eight city centers in the Kizılırmak Basin, which is the second biggest basin in Turkey. The trend analysis was carried out with the Mann-Kendall test using the data obtained from the Turkish State Meteorological Service, which belongs to a period of 38 years recorded between 1980-2017 years. Sen's trend test was also held to determine the amount of change. According to the results of trend analysis, it was revealed that there was a statistically significant increase in trends in stations. Furthermore, an increasing trend was designated in minimum, maximum and mean temperatures in the eight meteorological stations located in basin.
\end{abstract}

\section{Giriş}

Hidroklimatolojik veriler kullanılarak yapılan çalışmalar, küresel ısınma sebebiyle su kaynaklarının ciddi miktarda etkilendiğini göstermektedir. Hükümetlerarası İklim Değişikliği Panelinin 5 . Değerlendirme Raporunda da belirtildiği gibi meteorolojik parametrelerden sıcaklık ve yağıșta dünyanın farklı bölgelerinde kayda değer değişiklikler olmaktadır. Değerlendirme raporunda, dünya genelinde sicaklıkta meydana gelen değişikliklerin \%95-100 oranında insan aktivitelerinden kaynaklandığı kesin olarak ifade edilmiştir [1,2].

Hidroklimatolojik verilerin gidişlerini belirlemek bu verilerle yapılacak olan iklim değişikliği vb. çalışmalarda önem arz etmektedir. $\mathrm{Bu}$ amaçla kullanılan yöntemlerden biri trend analizidir. Trend analizi iki ya da daha fazla zamana bağlı değişkenin ilişkilerini matematiksel denklemlerle ifade etmek için geliştirilen veri analiz tekniklerinden birisidir. Trend analizi bağımsız değişkenin bilinen değerini referans alarak bağımlı değişkenin değerini tahmin etmek amacıyla yapılmaktadır [3].

Hidroklimatolojik zaman serilerinin trend analizinde yaygin olarak kullanılan parametrik testlerin uygun olmama sebepleri doğrusallık ve bağımsızlık gibi kabullere dayanmalarıdır. Bu yüzden, gözlemlerin sıralarını esas alan ve normal dağılım ya da herhangi bir dağılıma uyma şartı gerektirmeyen parametrik olmayan testler geliştirilmiştir. Parametrik olmayan testlerde kayıp değerler, kısıtlı veriler ve 
mevsimsellik gibi sorunlar ortadan kaldırılmaktadır [4].

Ülkemizin ve dünyanın birçok bölgesinde sıcaklığın trendini belirlemek amacıyla çeşitli çalışmalar yapılmıştır. Bağdatlı vd. (2014) Tekirdağ'ın Çorlu ilçesinde minimum, maksimum ve ortalama sıcaklığın trendini farklı yöntemlerle belirlemeye çalışmışlardır. Çalışmanın sonucunda sicaklıkların artan trend gösterdiğini ve bu durumun tarımı kötü etkileyeceğini tahmin ettiklerini belirtmişlerdir [5]. Cosun ve Karabulut (2009) Kahramanmaraş ilinde bulunan dört meteoroloji istasyonunun minimum, maksimum ve ortalama sıcaklık verilerine MannKendall ve lineer regresyon yöntemleriyle trend analizi uygulamışlardır. Yıllık sıcaklıklarda önemli artma trendi olduğunu, mevsimsel olarak da kış ve yaz mevsimlerinde istatistiksel olarak anlamlı trend olduğunu ifade etmişlerdir [6]. Ülke ve Özkoca (2018) Karadeniz bölgesinde bulunan Sinop, Ordu ve Samsun illerinin sıcaklık verilerindeki trendi Mann Kendall ve Sen'in trend testleriyle belirlemeye çalışmışlardır. Yapmış oldukları analizler sonucunda sıcaklıklarda artış trendi olduğunu ifade etmişlerdir [7]. Özfidaner vd. (2019), Adana il merkezi meteoroloji istasyonun sıcaklık verilerini kullanarak yapmış oldukları trend analizi çalışmasında minimum sıcaklıklarda yıl boyu artış trendi, maksimum sıcaklıklarda ise yedi ayda artış trendi sonucuna ulaştıklarını ifade etmişlerdir [8]. Yu vd. (2019) Çin'de bulunan 590 meteoroloji istasyonuna ait 46 yıllık maksimum ve minimum sicaklık verisine trend analizi uygulamışlardır. Minimum sıcaklıklardaki trendlerin maksimumdaki trendlere göre çok daha önemli olduğunu tespit etmişlerdir [9].

$\mathrm{Bu}$ çalışmada, Kızılırmak Havzası'nda il merkezlerinde bulunan meteoroloji istasyonlarına ait sıcaklık verilerinin trend analizleri yapılmıştır. 38 yıllık sıcaklık verilerinin aylık, mevsimlik ve yıllık trendleri belirlenmiştir. Mart, Nisan, Mayıs ayları ilkbahar mevsimi, Haziran, Temmuz, Ağustos ayları yaz mevsimi, Eylül Ekim, Kasım ayları sonbahar mevsimi ve Aralık, Ocak, Şubat ayları kış mevsimi olacak şekilde ayrılmışlardır. Elde edilen bulgular doğrultusunda çalışma bölgesinde sıcaklık değerlerinde trend var olup olmadığı belirlenerek geleceğe ait fikir sahibi olunması amaçlanmıştır.

\section{Materyal ve Metot}

\section{1. Çalışma bölgesi ve veriler}

Ülkemizde İç Anadolu Bölgesinin doğusunda yer alan Kızılırmak Havzası Türkiye'nin ikinci en büyük havzasıdır. Yalnızca kuzey ve doğu kesimleri dağlık iken, büyük bir bölümü tepelik alan olan havza ülke topraklarının yaklaşık \%11'ini kaplar. Türkiye'nin en uzun akarsuyu olan Kızılırmak, 1.151 km uzunluğa ve
$78.180 \mathrm{~km}^{2}$ lik bir drenaj alanına sahiptir. Sivas İmranlı civarından doğup Kayseri, Nevşehir, Aksaray, Kırşehir, Ankara, Kırıkkale, Çankırı, Çorum, Sinop ve Samsun illerinden geçerek Bafra Ovası'ndan Karadeniz'e dökülmektedir [10]. Kızılırmak Havzası'nın haritası Şekil 1'de verilmektedir[11].

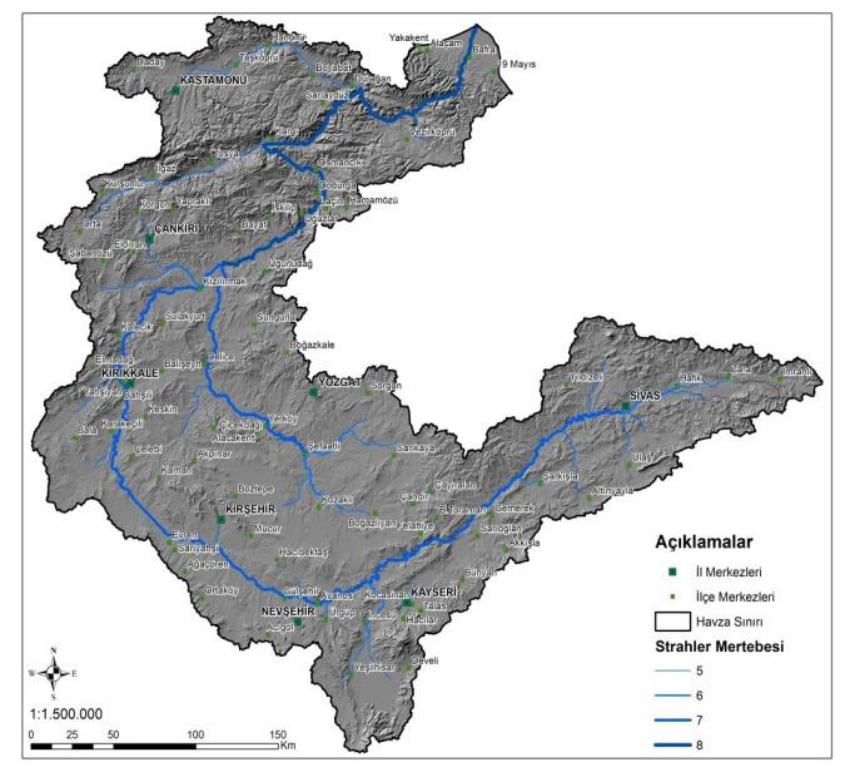

Şekil 1. Kızılırmak Havzası haritası [11].

Kızılırmak Havzası'nın toplam alanı 8.210.007 hektardır. $72.278 \mathrm{~km}^{2}$ yağıș alanına sahip olan havzanın yıllık ortalama yağış yüksekliği $446 \mathrm{~mm}$; yıllık ortalama akışı ise $164,15 \mathrm{~m}^{3} / \mathrm{s}^{\prime}$ dir. Yıllık ortalama yağış verimi $2,6 \mathrm{~L} / \mathrm{s} / \mathrm{km}^{2}$ olan havzadaki akışın yağışa iştirak oranı \% 3,5'dir [10]. Havzanın en önemli dereleri Delice Irmağı ve dağlık kuzey kesiminin sularını toplayan Devrez Çayı ve Gökırmak'dır. İmranlı'da birçok derenin birleşmesiyle oluşan Kızılırmak Nehri'ne, Sivas il sinırları içinde Acısu, Hafik, Mısmıl, Tecer, Koru, Yıldız, Kalın ve Göksu karışmaktadır. Kayseri'nin sularını toplayan Karasu, Kızılırmak Nehri'ni beslemektedir. Balaban Deresi Bala ilçesinin batı kesiminin sularını toplayarak Kırıkkale'den sonra Kızılırmak Nehri'ne katılmaktadır. Çankırı-Şabanözü dolaylarının sularını toplayarak batıdan gelen Terme ve Acı Çay ile İskilip ve Bayat kuzeyinden gelen Bayat, Ovacık Çayı ve Değirmen Dere Kızılırmak'la birleşmektedir [10].

Çalışmada kullanılan veriler Devlet Meteoroloji İşleri Genel Müdürlüğü'nden temin edilmiştir. Kızılırmak Havzası sınırları içindeki sekiz il merkezinde bulunan meteoroloji istasyonlarına ait 1980-2017 yılları arasındaki 38 yıllık, aylık minimum, maksimum ve ortalama sıcaklık verileri kullanılmıştır. Temin edilen veriler günlük veriler olup, aylığa çevrilerek trend analizi işlemi uygulamaya hazır hale getirilmiştir. Çalışmada kullanılan istasyonlara ait bilgiler Tablo 1 'de verilmiștir. 
Tablo 1. Meteoroloji istasyonlarına ait bilgiler

\begin{tabular}{clcccccc}
\hline $\begin{array}{c}\text { İstasyon } \\
\text { No }\end{array}$ & $\begin{array}{c}\text { İstasyon } \\
\text { Adı }\end{array}$ & Enlem & Boylam & $\begin{array}{c}\text { Yükseklik } \\
(\mathrm{m})\end{array}$ & $\begin{array}{c}\text { Minimum } \\
\left({ }^{\circ} \mathrm{C}\right)\end{array}$ & $\begin{array}{c}\text { Maksimum } \\
\left({ }^{\circ} \mathrm{C}\right)\end{array}$ & $\begin{array}{c}\text { Ortalama } \\
\left({ }^{\circ} \mathrm{C}\right)\end{array}$ \\
\hline 17090 & Sivas & 39,7437 & 37,002 & 1294 & $-15,68$ & 33,86 & 9,22 \\
17196 & Kayseri & 38,687 & 35,5 & 1094 & $-14,21$ & 35,41 & 10,60 \\
17193 & Nevșehir & 38,6163 & 34,7025 & 1260 & $-10,48$ & 33,55 & 10,77 \\
17160 & Kirșehir & 39,1639 & 34,1561 & 1007 & $-10,75$ & 34,47 & 11,54 \\
17140 & Yozgat & 38,8205 & 34,8159 & 1301 & $-11,59$ & 31,73 & 9,29 \\
17135 & Kirıkkale & 39,8433 & 33,5181 & 751 & $-8,81$ & 35,59 & 12,50 \\
17080 & Çankırl & 40,6086 & 33,6102 & 755 & $-9,63$ & 36,56 & 11,25 \\
17074 & Kastamonu & 41,371 & 33,7756 & 800 & $-9,96$ & 33,48 & 9,76 \\
\hline
\end{tabular}

\subsection{Trend analizi}

Rastgele bir değişkenin değerlerinde zamana bağlı olarak azalma ya da artış olması trend olduğunu göstermektedir. Yağış ve sıcaklık gibi iklim parametreleri değişken olduğu için su miktarlarının zaman içerisindeki trendlerini bilmek yapılacak çalışmalarda önemli olmaktadır. Bununla birlikte hidrolojik verilerin uzun süreli gözlemlerinin ve salınımlarının dikkate alınması da gerekmektedir [3] .

Hidroklimatolojik zaman serilerinin trend analizinde lineer regresyon modeli gibi parametrik testler kullanılmaktadır. Ancak klasik parametrik testler normalite, doğrusallık ve bağımsızlık gibi kabullere dayandığından yağış, akış gibi zaman serilerinin analizi için genellikle uygun olmadıklarından parametrik olmayan testler geliștirilmiștir. Bu testler gözlemlerin büyüklüğü yerine sıralarını dikkate alırlar ve herhangi bir dağılıma uyma şartı gerektirmezler. Ayrıca kayıp değerler, kısıtlı veriler ve mevsimsellik gibi problemlerde parametrik olmayan testler kullanılabilmektedir [4]. Bu çalışmada, Kızılırmak Havzası'nda sıcaklık verilerinin trendlerinin araştırılmasında kullanılan trend analizi testleri aşağıda verilmiştir.

\subsubsection{Mann-Kendall testi}

Akarsu akımı, sıcaklık, yağış ve su kalitesi gibi hidrometeorolojik verilerin zaman serilerindeki eğilimlerin önemini irdelemek için sıklıkla kullanılan Mann-Kendall testi, sira tabanlı parametrik olmayan istatistik bir testtir. Parametrik olmayan istatistiksel testleri kullanmanın temel nedeni, parametrik istatistiksel testlerle karşılaştırıldığında, parametrik olmayan testlerin, normal olarak dağılmamış veriler ve hidrometeorolojik zaman serilerinde sıç̧a karşılaşılan sansürlü (kısıtlı) veriler için daha uygun olduğunun düşünülmesidir [12].

Mann-Kendall test istatistiği (1) eşitliğiyle hesaplanır. $\mathrm{Bu}$ eşitlikteki $\left(\mathrm{x}_{j}\right.$ - $\left.\mathrm{x}_{k}\right)$ değerinin işareti (2) ifadesi ile bulunur.

$$
S=\sum_{k=1}^{n-1} \sum_{j=k+1}^{n} \operatorname{sgn}\left(x_{j}-x_{k}\right)
$$

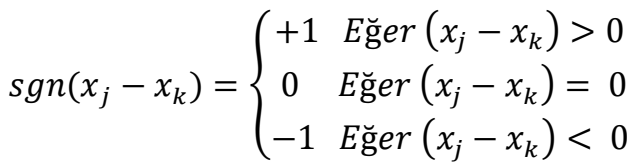

Asimptotik olarak normal bir dağllıma sahip ve ortalama sıfır olan test istatistiği $S$ 'in varyansı (3) eşitliğiyle hesaplanır. Burada " $n$ " gözlem sayısını göstermektedir.

$$
\operatorname{Var}(S)=\frac{n(n-1)(2 n+5)}{18}
$$

Eğer zaman serisinde benzer değerler sözkonusu ise varyans eşitlik (4) ile hesaplanır. Burada " $t$ " zamanı ifade etmektedir.

$$
\operatorname{Var}(S)=\frac{n(n-1)(2 n+5)-\sum_{t} t(t-1)(2 t+5)}{18}
$$

Mann-Kendall testinin varyansı belirlendikten sonra önemi, standart normal değişken $z$ eşitlik (5) ile hesaplanır ve kritik $z$ değeriyle karşılaştırılarak belirlenir.

$$
z=\left\{\begin{array}{llc}
\frac{S-1}{\sqrt{\operatorname{Var}(S)}} & \text { Ĕger } & S>0 \\
0 & \text { Ĕer } & S=0 \\
\frac{S+1}{\sqrt{\operatorname{Var}(S)}} & \text { Ĕger } & S<0
\end{array}\right\}
$$

$\mathrm{H}_{0}$ hipotezi, seçilen $\alpha$ anlamlılık seviyesinde $|\mathrm{z}| \leq \mathrm{z}_{\alpha}$ ise kabul edilir, aksi durumda reddedilir. $S$ değeri pozitif çıktıysa artan trend, negatif çıktıysa azalan bir trend vardır. $\mathrm{Bu}$ yöntemde verilerin belirli bir dağılıma uyma zorunluluğu aranmadığı için ve eksik verilerin varlığına izin verdiği için kullanışlıdır $[13,14]$.

\subsubsection{Sen'in trend testi}

Parametrik olmayan ve Sen (1968) tarafindan geliştirilen bu test, doğrusal bir trend varsa birim zamandaki değişim yani gerçek eğim için veri hatalarından veya ekstrem değerlerden etkilenmeyen, eksik değerlerin olduğu kayıtlara uygulanabilir [13]. Burada, $j$ ve $k$ zamanlarındaki veriler $x_{j}$ ve $x_{k}(j>k)$ ve veri sayısı $n$ olmak üzere, 


$$
N=n(n-1) / 2
$$

adet ise $Q_{\text {i }}$ parametresi:

$$
Q_{i}=\frac{\left(x_{j}-x_{k}\right)}{j-k}(i=1, \ldots, N)
$$

bağıntısı ile hesaplanır. Böylece tüm $Q_{i}$ değerleri küçükten büyüğe doğru sıralanır. Hesaplanan $N$ adet $Q_{i}$ değerinin medyanı doğrusal trendin eğimini verir. N sayısı tek olduğunda (8) eşitliği,

$$
Q_{\text {medyan }}=Q_{(N+1) / 2}
$$

çift olduğunda ise (9) eşitliği,

$$
Q_{\text {medyan }}=\frac{\left|Q_{N / 2}+Q_{(N+2) / 2}\right|}{2}
$$

kullanılır ve gözlemlerin birim zamandaki değişimi bulunur. Pozitif değer artan yönde, negatif değer ise azalan yönde bir eğilimi gösterir $[15,16]$.

\section{Bulgular}

Kızılırmak Havzası sınırları içindeki sekiz il merkezinde bulunan meteoroloji istasyonlarına ait minimum, maksimum ve ortalama sicaklık verilerine 38 ylllk dönemde (1980-2017) bir trend olup olmadığını belirlemek amacıyla parametrik olmayan Mann-Kendall testi ile trend analizi uygulanmıştır. Sıcaklık verilerinde trend olup olmadığ $\% 95$ güven aralığında değerlendirilmiştir. Buna göre $Z$ değeri 1,96'ya eşit ya da büyük ise artan trend olduğu, 1,96'ya eşit ya da küçük ise azalan trend olduğu kabulü yapılmıştır. $Z$ değeri \pm 1.96 değerleri arasında ise bir trend olmakla birlikte istatistiksel olarak anlamlı olmadığından trend yoktur kabulü yapılmıştır. Sen'in trend testi ise birim zamandaki değişim miktarını belirlemek için kullanılmıştır.

\subsection{Minimum sıcaklıkların trend analizi}

Minimum sıcaklıkların trend analizi sonuçları incelendiğinde, Ocak, Nisan, Kasım ve Aralık aylarında sekiz meteoroloji istasyonunun hiçbirinde istatistiksel açıdan anlamlı trend gözlenmemiştir. Diğer taraftan Ağustos ve Eylül aylarında, sonbahar döneminde ve yıllıkta bütün meteoroloji istasyonlarında anlamlı bir artış trendi olduğu belirlenmiştir (Ek A). Havza sınırları içerisinde bulunan sekiz il merkezine ait meteoroloji istasyonunun trend analizine göre, Kayseri il merkezi meteoroloji istasyonunun dışındaki yedi istasyonda yaz döneminde artış trendi olduğu tespit edilmiştir. Kış döneminde Kayseri istasyonu dışındaki istasyonlarda trend olmadığı tespit edilmiştir. Ek A'da verilen Sen'in trend testine göre birim zamandaki değişim miktarları incelendiğinde; istatistiksel olarak anlamlı trend gözlenen aylar, dönemler ve yıllıkta değişim miktarı $0,021{ }^{\circ} \mathrm{C} /$ yıl ile $0,144^{\circ} \mathrm{C} /$ yıl arasında değişmektedir. En az değişim miktarının 0,021 ${ }^{\circ} \mathrm{C} / \mathrm{yl}$ ile Kastamonu istasyonunun yıllığında, en çok değişim miktarının ise $0,144{ }^{\circ} \mathrm{C} /$ yıl ile Kayseri istasyonunun Ağustos ayında meydana geldiği görülmüştür.

\subsection{Maksimum sıcaklıkların trend analizi}

Kızılırmak Havzası sınırları içinde bulunan il merkezleri meteoroloji istasyonlarına ait maksimum sıcaklık verilerinin trend analizi sonuçlarına göre sekiz istasyonun tamamında Temmuz ve Ağustos aylarında, ilkbahar ve yaz dönemlerinde $\% 95$ güven aralığında istatistiksel olarak anlamlı artış trendi olduğu belirlenmiștir. Haziran ayında Kastamonu istasyonu haricindeki istasyonlarda anlamlı artış trendi tespit edilmiştir. Ayrıca yıllık olarak da bütün istasyonlarda anlamlı bir artış trendi olduğu Ek B'de görülmektedir. Sonbahar döneminde Kayseri istasyonu hariç diğer istasyonlarda artış trendi olduğu gözlenmiştir. Sivas ve Yozgat istasyonlarında kış döneminde anlamlı artış trendi gözlenirken, diğer istasyonlarda anlamlı trend gözlenmemiştir. Ocak, Nisan, Eylül, Ekim ve Aralık aylarında sekiz istasyonun tamamında istatistiksel olarak anlamlı trend tespit edilmemiştir. Yukarıda belirtilen anlamlı artış trendinin görüldügü aylar, dönemler ve yıllık dışında sekiz istasyonda Çankırı istasyonu Ocak ayı hariç bütün aylar, dönemler ve yıllıkta artış trendi olduğu, ancak bu trendler istatistiksel olarak anlamlı olmadığından trend olmadığı değerlendirilmesi yapılmıştır. Çankırı istasyonu Ocak ayında ise istatistiksel açıdan anlamsız azalma trendi olduğu belirlenmiştir. İstatiksel olarak anlamlı trendin görüldüğü noktalarda en düşük artış miktarı 0,046 ${ }^{\circ} \mathrm{C} / \mathrm{y}$ ll ile Kayseri istasyonunun yıllığında, en yüksek artış miktarı $0,126^{\circ} \mathrm{C} / \mathrm{yll}$ ise Yozgat istasyonun şubat ayında olduğu tespit edilmiștir.

\subsection{Ortalama sıcaklıkların trend analizi}

Ortalama sıcaklıkların trend analizi sonuçlarının verildiği Ek C'den de görüldüğü üzere, Ocak, Nisan, Ekim, Kasım ve Aralık aylarında havza sınırları içinde bulunan sekiz istasyonun tamamında istatistiksel olarak anlamlı trend olmadığı tespit edilmiştir. Ayrıca kış döneminde de hiçbir istasyonda anlamlı trend olmadığı gözlenmiștir. İstatistiksel olarak anlamsız olmakla birlikte gözlenen trendler artış trendi şeklindedir. Havza sınırları içinde kalan il merkezlerindeki meteoroloji istasyonlarının ortalama sıcaklık verilerinin trend analizine göre, sekiz istasyonun tamamında Haziran, Temmuz, Ağustos aylarında, ilkbahar, yaz, sonbahar dönemlerinde 0,05 anlamlılı seviyesine göre anlamlı artış trendi olduğu belirlenmiştir. Bununla birlikte analizi yapılan bütün istasyonlarda yıllık olarak istatistiksel açıdan anlamlı artış trendi olduğu Ek C'den görülmektedir. Yukarıda belirtilen anlamlı ve anlamsız trendlerin dışında kalan noktalara bakıldığında trendlerin büyük 
çoğunluğu anlamsız olmakla birlikte artış trendi şeklindedir. Sadece Kırşehir ve Kastamonu istasyonları Ocak ayı, ve Kırıkkale, Çankırı ve Kastamonu istasyonlarında ise Aralık ayı trendleri azalma trendi şeklindedir. Azalma trendi olmakla birlikte $\% 95$ güven aralığına göre değerlendirildiğinde bu noktalarda $z$ değeri belirtilen kriterlerin dışında kaldığı için trend yoktur kabulü yapılmıştır. Tespit edilen anlamlı artış trendlerine bakıldığında, değişim miktarının $0,032{ }^{\circ} \mathrm{C} / \mathrm{yll}$ ile $0,104{ }^{\circ} \mathrm{C} /$ yıl arasında değiștiği belirlenmiștir.

\section{Tartıșma ve Sonuç}

Kızılırmak havzasında bulunan sekiz il merkezinin meteoroloji gözlem istasyonlarına ait veriler Devlet Meteoroloji İşleri Genel Müdürlügü'nden alınarak 1980-2017 yılları arasındaki 38 yıllık döneme trend analizi işlemi uygulanmıştır. $\mathrm{Bu}$ istasyonların minimum, maksimum ve ortalama sicaklık verilerine ayrı ayrı aylık, mevsimlik ve yıllık olmak üzere trend analizi uygulanmıştır. Trend analizi sonuçlarında sekiz istasyonun hepsinde minimum, maksimum ve ortalama sıcaklıklarda Ağustos ayında anlamlı artıș trendi olduğu tespit edilmiştir. Yıllık trende bakıldığında çalışma kapsamındaki istasyonların tamaminda minimum, maksimum ve ortalama sıcaklıklarda anlamlı artış trendi olduğu gözlenmiştir. Ayrıca burada belirtilen anlamlı artış trendlerinin dışında aylar ve dönemlerin birçoğunda anlamlı artış trendi olduğu, anlamsız olduğu için trend yoktur kabulü yapılan birçok noktada da artış trendi olduğu tespit edilmiştir. Sadece birkaç noktada anlamsız azalma trendi olduğu belirlenmiştir. $\mathrm{Bu}$ sonuçlar doğrultusunda teste tabi tutulan istasyonların sıcaklıklarında artış trendi olduğu rahatlıkla söylenebilir.

Çalışmada değerlendirmeye alınan istasyonlardaki sıcaklıkların artış trendinde olması istasyonların şehir merkezlerinde olmasıyla ilgili olabilir. Nitekim şehir merkezlerinde şehirleşmenin, sanayinin hızla gelişmesi nüfusu da hızla arttırmaktadır. Bu gelişmeler enerji tüketimini, trafiği ve betonlaşmayı arttırırken yeşil alanları azaltmakta bu da radyasyon dengesini değiştirmektedir. Radyasyon dengesinin değişimiyle sıcaklık, yağış gibi parametrelerde zamanla farklılaşmalar meydana gelmektedir [17].

Sıcaklık ve yağış gibi faktörlerde meydana gelen değişiklikleri kapsayan iklim değişikliğinin su kaynakları üzerine etkileri suyun yönetimi açısından önemli olmaktadır. Diğer taraftan iklim değişikliği kaynaklı buharlaşma ve yağış rejimlerinin değişmesiyle birlikte kuraklık ve taşkın riskleri doğabileceği dolayısıyla yeraltı ve yerüstü su kaynaklarının da uzun vadede etkilenebileceği bilinmektedir. Su kaynaklarının etkilenmesiyle birlikte tarım, enerji, arazi kullanımı, hayvancılık gibi birçok parametre de etkilenecektir.
Sen'in trend testi ile belirlenen değişim miktarları incelendiğinde; minimum sıcaklıklarda en büyük artış miktarının bütün istasyonlarda Ağustos ayında meydana geldiği tespit edilmiştir. Bununla birlikte sekiz meteoroloji istasyonu içinde en büyük artış miktarı $0,144{ }^{\circ} \mathrm{C} / \mathrm{yll}$ ile Kayseri meteoroloji istasyonunda meydana gelmiştir. Minimum sıcaklıklardaki en fazla artışın havza genelinde Ağustos ayında olması dikkat çekicidir. Maksimum sıcaklıklardaki en büyük artış miktarının sekiz meteoroloji istasyonun tamamında Şubat ayında gerçekleştiği belirlenmiştir. Yozgat meteoroloji istasyonu $0,126{ }^{\circ} \mathrm{C} / \mathrm{yll}$ ile en fazla artışı gösteren meteoroloji istasyonu olmuştur. Maksimum sıcaklıklardaki en büyük artış miktarının bütün istasyonlarda kış mevsimine ait olan Şubat ayında gerçekleşmiş olmasının önemli olduğu düşünülmektedir. Ortalama sıcaklıkların artış miktarı incelendiğinde; Yozgat meteoroloji istasyonu dışındaki istasyonlarda en büyük artış miktarı Ağustos ayında meydana gelirken, Yozgat meteoroloji istasyonunda Şubat ayında meydana geldiği tespit edilmiştir. Sekiz meteoroloji istasyonu içinde en büyük artış miktarının 0,104 ${ }^{\circ} \mathrm{C} /$ yll ile Nevşehir meteoroloji istasyonunda olduğu belirlenmiştir. Sıcaklık değerlerindeki değişim miktarları ve meydana geldikleri yerler incelendiğinde havza genelinde bir bütünlük olduğunu söylemek mümkündür. Havzanın genelinde sıcaklıklar açısından aynı karakteristik özellikleri gösterdiği düşünülmektedir.

Sıcaklıklarda artış trendi olmasıyla birlikte yağışta olası bir azalma trendinin gelecekte kuraklığa sebep olabileceği ve tarımsal faaliyetleri olumsuz etkileyebileceği tahmin edilmektedir. Yayınlanan emisyon senaryoları ve iklim modellerinin birçoğunda dünyanın farklı bölgelerinde sıcaklıkların gelecek dönemlerde artacağı öngörülmektedir. Çalışma bölgesindeki sıcaklıklardaki artış trendi olması bu öngörüyü desteklemektedir.

\section{Kaynakça}

[1] IPCC, 2013. Fifth Assessment Report of the Intergovernmental Panel on Climate Change. Cambridge University Press, 1535s.

[2] Kankal, M., Akçay, F. 2019. Trabzon İliYağışlarının Eğilim Analizi. Gümüşhane Üniversitesi Fen Bilimleri Enstitüsü Dergisi, (2), 318-331.

[3] Cebe, E. N. 2007. Türkiye akarsularında mevsimsel trend analizi. İstanbul Teknik Üniversitesi Fen Bilimleri Enstitüsü, Yüksek Lisans Tezi, 72s, İstanbul.

[4] Partal, T. 2002. Türkiye yağış verilerinin trend analizi. İstanbul Teknik Üniversitesi Fen Bilimleri Enstitüsü, Yüksek Lisans Tezi, 92s, İstanbul. 
[5] Bağdatlı, M. C., İstanbulluoğlu, A., Altürk, B., Arslan, C. 2014. Uzun Yillı Sicaklık Verilerindeki Değişim Trendinin Tarımsal Kuraklık Açısından Değerlendirilmesi: Çorlu Örneği. Düzce Üniversitesi Bilim ve Teknoloji Dergisi, 2(1), 100-107.

[6] Cosun, F., Karabulut, M. 2009. Kahramanmaraș'ta Ortalama, Minimum ve Maksimum Sicaklıkların Trend Analizi. Türk Coğrafya Dergisi, (53), 41-50.

[7] Ülke, A., Özkoca, T. 2018. Sinop, Ordu ve Samsun İlerinin Sicaklı Verilerinde Trend Analizi. GÜFBED, 8(2), 455-463.

[8] Özfidaner, M., Şapolyo, D., Topaloğlu, F. 2019. Adana ilinde maksimum ve Minimum Sıcaklıkların Gidiş Analizi. Mediterranean Agricultural Sciences, 32(2), 237-241.

[9] Yu, D. L., Li, W. J., Zhou, Y. 2019. Analysis of Trends in Air Temperature at Chinese Stations Considering the Long-Range Correlation Effect. Physica A: Statistical Mechanics and its Applications, 533, 122034, 1-11.

[10] Tübitak MAM. (2010). Havza Koruma Eylem Planlarının Hazırlanması - Kızılırmak Havzası. T.C. Orman ve Su İşleri Bakanlığı adına TÜBİTAK Marmara Araştırma Merkezi. 529s.

[11] Anonim, 2019. https://www.tarimorman.gov.tr/ SYGM/FotografGalerisi/KIZILIRMAK\%20HAVZA SI09.08.2019/02.jpg (Erişim Tarihi: 13.08.2020).
[12] Yue, S., Pilon, P., Cavadias, G. 2002. Power of the Mann-Kendall and Spearman's Rho Tests for Detecting Monotonic Trends in Hydrological Series. Journal of hydrology, 259(1-4), 254-271.

[13] Yu, Y. S., Zou, S., Whittemore, D. 1993. NonParametric Trend Analysis of Water Quality Data of Rivers in Kansas. Journal of Hydrology, 150(1), 61-80.

[14] Büyükyıldız, M., Berktay, A. 2004. Parametrik Olmayan Testler Kullanilarak Sakarya Havzasi Yağișlarinin Trend Analizi. Selçuk Üniversitesi Mühendislik, Bilim ve Teknoloji Dergisi, 19(2), 23-38.

[15] Sen, P. K. 1968. Estimates of the Regression Coefficient Based on Kendall's Tau. Journal of the American statistical association, 63(324), 1379-1389.

[16] Soydan, N. G., Gümüş, V., Şimşek, O., Gerger, R., Ağun, B. 2016. Seyhan Havzası Aylık Ortalama Akım ve Yağış Verilerinin Trend Analizi. DÜMF Mühendislik Dergisi, 7(2), 319-327.

[17] Çiçek, İ., Doğan, U. 2005. Ankara'da Şehir Isı Adasının İncelenmesi. Coğrafi Bilimler Dergisi, 3(1), 57-72. 


\section{Ekler}

Ek A. Ortalama aylık minimum sıcaklık değerlerinin trend analizi sonuçları

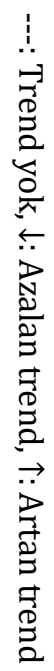<smiles>CCCCCC</smiles>

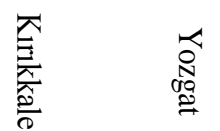

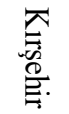

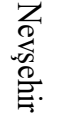

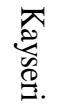

$\underset{\infty}{\infty}$

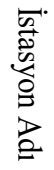

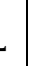

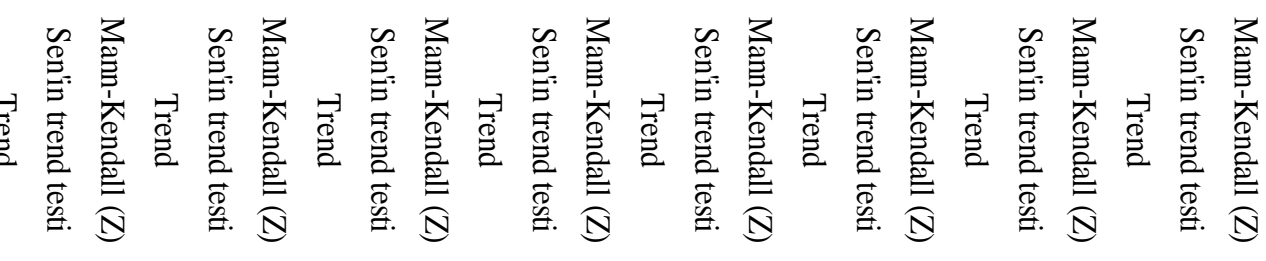

怘

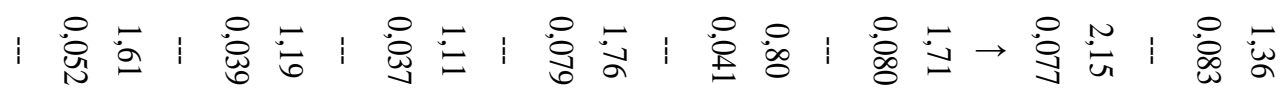

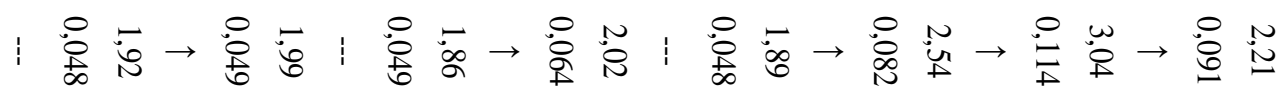

|

|

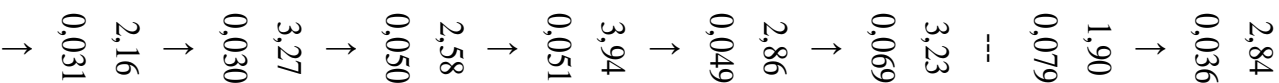

兽

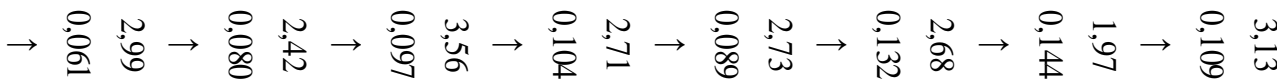

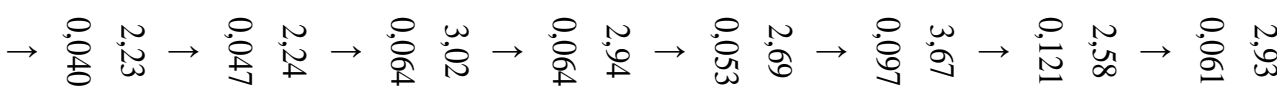

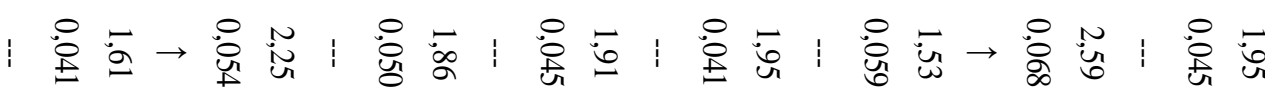

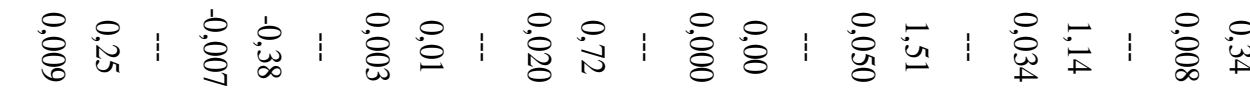

它家|

|

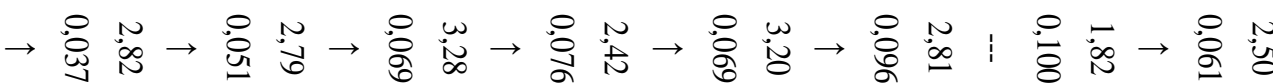

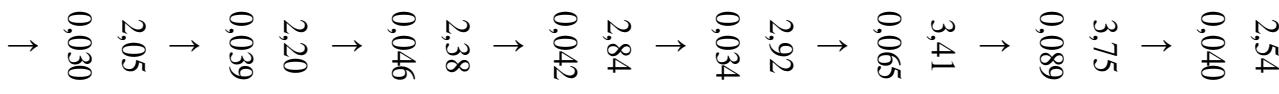

|

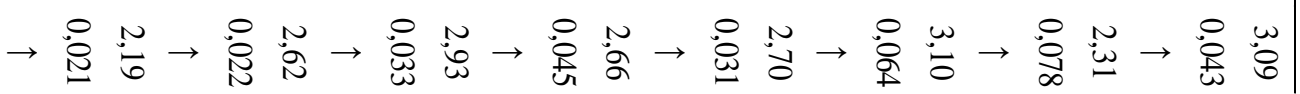


Ek B. Ortalama aylık maksimum sıcaklık değerlerinin trend analizi sonuçları

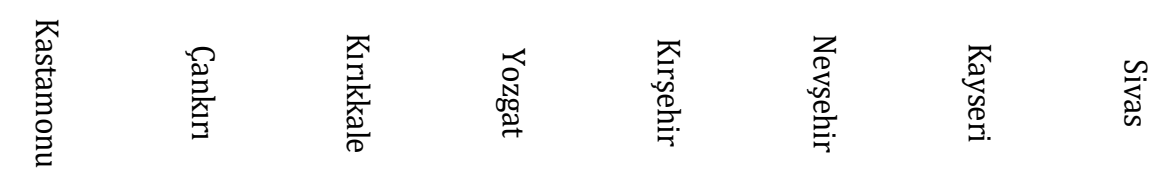

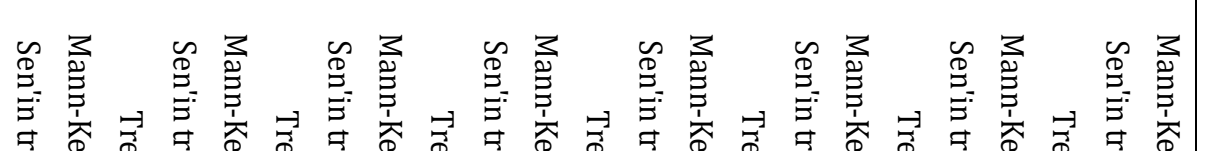

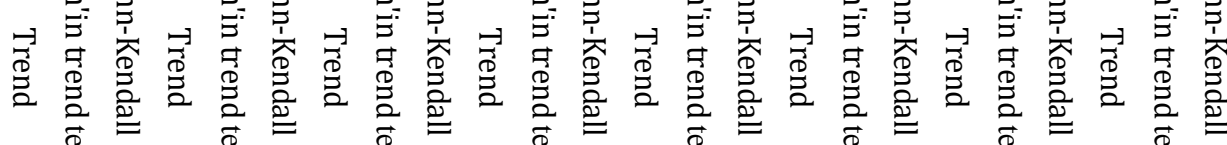

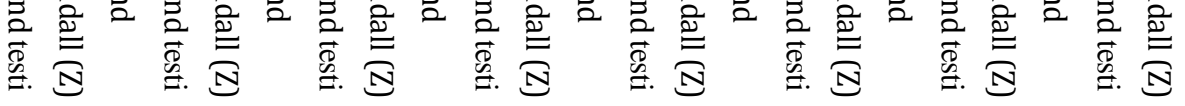

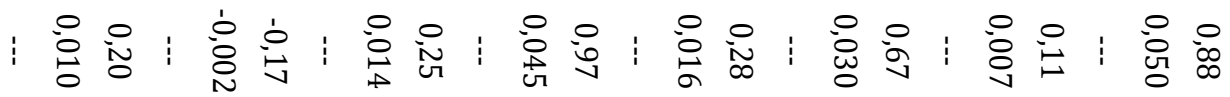

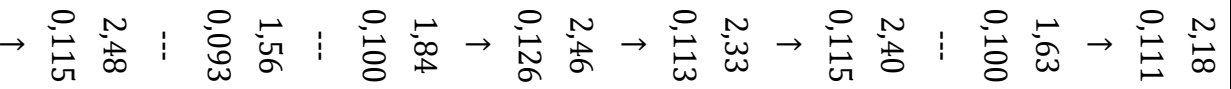

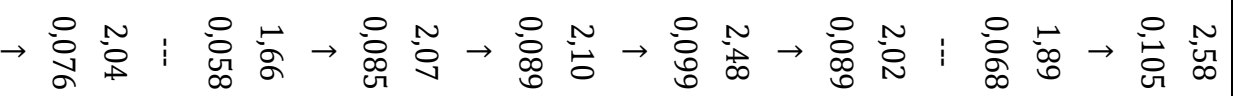

|

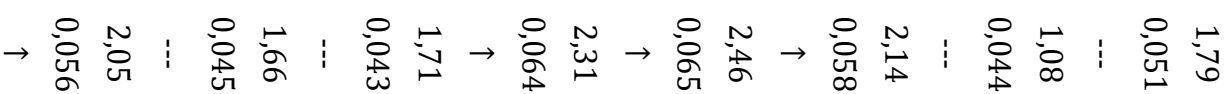

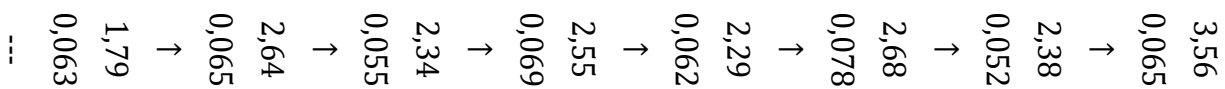

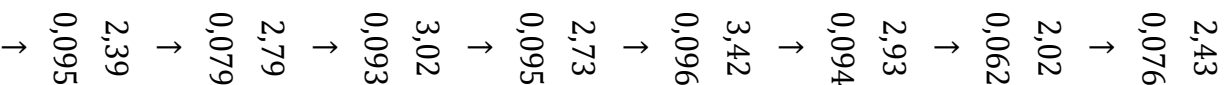

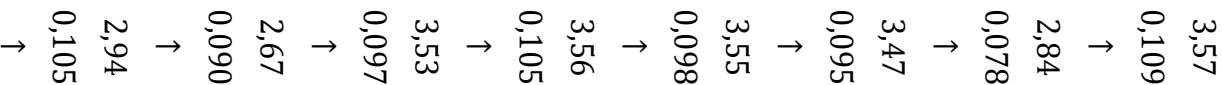

; \begin{tabular}{l}
$\circ$ \\
\hline
\end{tabular}

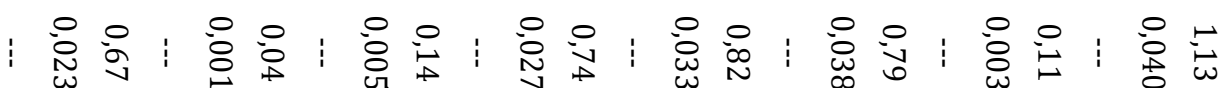

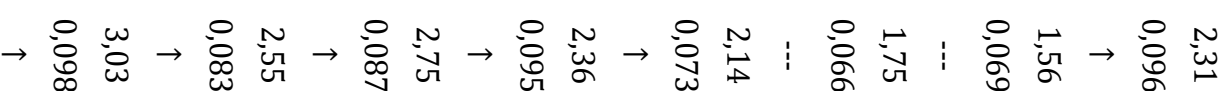

|

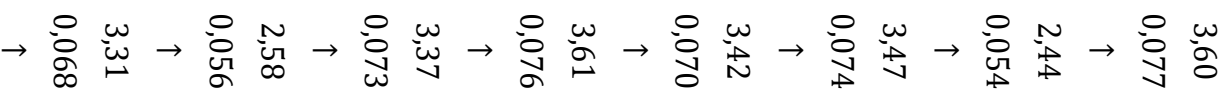

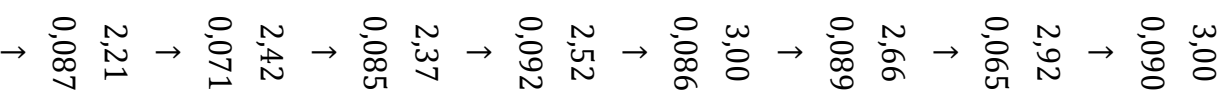

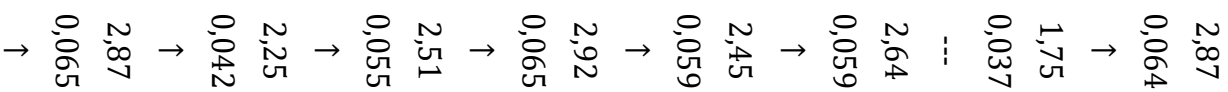

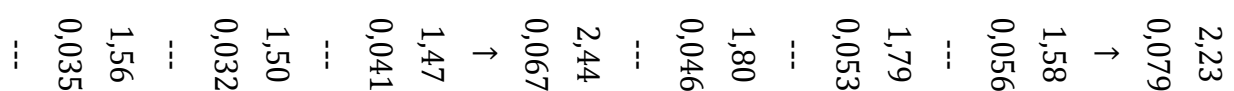

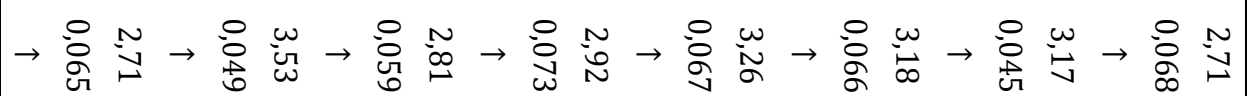


Ek C. Aylık ortalama sıcaklık değerlerinin trend analizi sonuçları

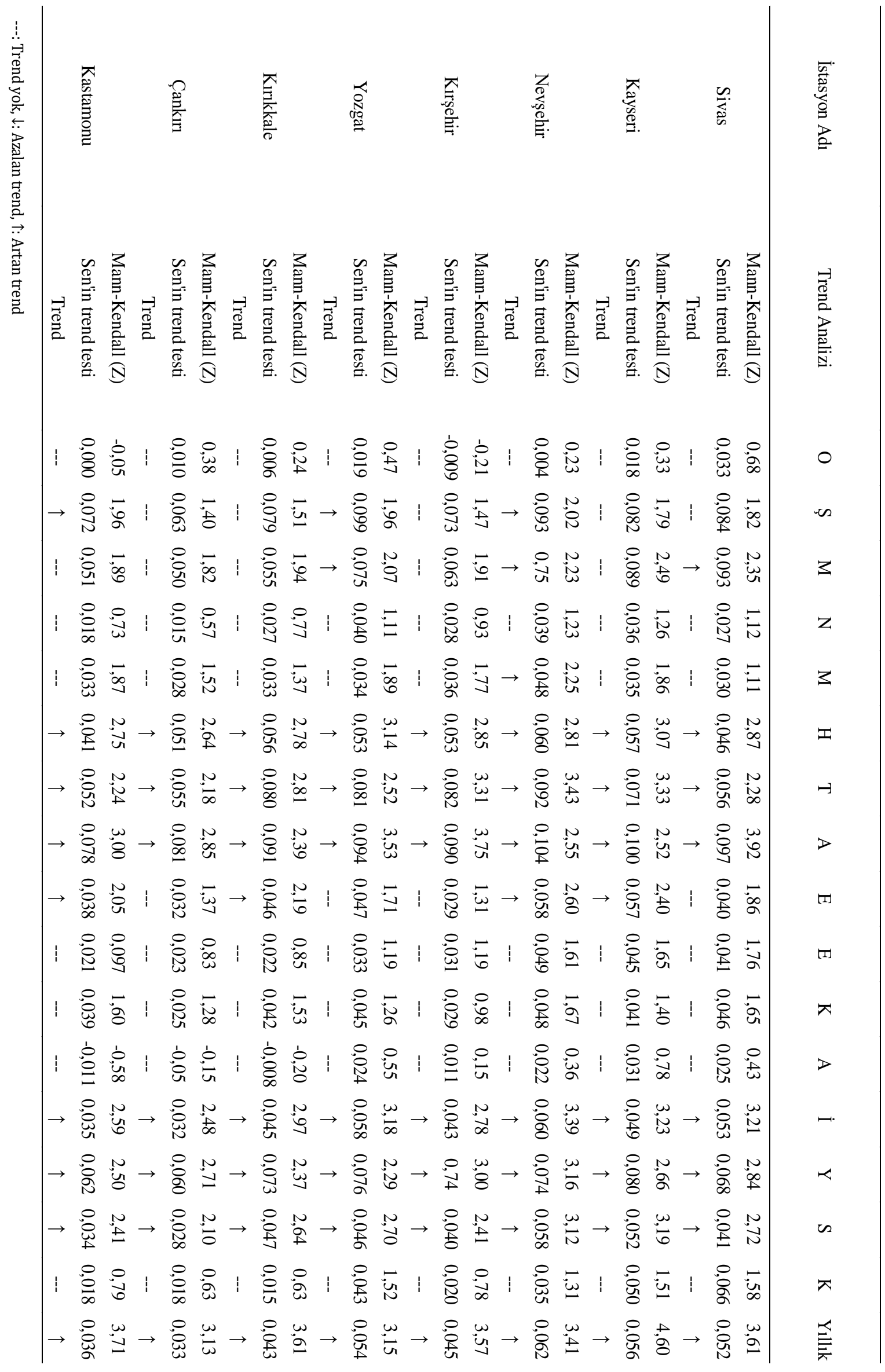

